\title{
Candida bituminiphila, a novel anamorphic species of yeast
}

1 Centraalbureau voor Schimmelcultures (CBS), Yeast Division, Uppsalalaan 8, $3584 \mathrm{CT}$ Utrecht, The Netherlands

2 Rue du vivier, 28, B-1401 Baulers, Belgium

3 DSM Biotech GmbH, Karl Heinz Beckurtsstrasse 13, D-52428 Juelich, Germany

\author{
Vincent Robert, ${ }^{1}$ Bernard Bonjean, ${ }^{2}$ Martin Karutz, ${ }^{3}$ Holger Paschold ${ }^{3}$ \\ Wilco Peeters ${ }^{3}$ and Marcel G. Wubbolts ${ }^{3}$
}

Author for correspondence: Vincent Robert. Tel: +31 030 2122600. Fax: +31 0302512097. e-mail: robert@ cbs.knaw.nl

\begin{abstract}
A novel anamorphic species of yeast belonging to the genus Candida was isolated from tar in Canada. Morphological and physiological observations, as well as phylogenetic analyses, were performed. Conidiophores were produced, were usually short and had sympodial growth, numerous bud scars and a rachis-like structure. They bore one or more conidia. Pseudomycelium was scarcely produced and true mycelium was sparse. No sexual reproduction was observed on corn meal, malt, Gorodkowa, Dextrose Yeast Peptone or V8 agars. Zygoascus hellenicus was physiologically the most closely related species, but it differed from the novel species by its ability to assimilate D-galacturonate and L-rhamnose, ferment sucrose and grow at $37^{\circ} \mathrm{C}$. From sequence analysis of the 26S rDNA D1/D2 region, $Z$. hellenicus and Candida bertae var. bertae were the closest species with 54 and 56 bp substitutions, respectively. Similar results have been obtained from analysis of the 185 rDNA. All these data support the hypothesis that the yeast, named Candida bituminiphila, is a novel species closely related to $Z$. hellenicus. The holotype and only isolate of $C$. bituminiphila is strain CBS $8813^{\top}$ ( = MUCL 41424').
\end{abstract}

Keywords: Candida bituminiphila, 26S and 18S rDNA gene sequences, phylogenetics, phenetic study

\section{INTRODUCTION}

During the study of a series of strains for a scientific identification service, a novel, interesting ascomycetous yeast was found. Details about the origin of the strain remained vague since the only information available about the yeast was the country of origin, Canada, and the substrate of isolation, bitumen. The strain was recognized as potentially novel by physiological identification methods (Robert et al., 1994, 1997). Sequencing of the D1/D2 domain of the largesubunit (26S) rDNA as well as the complete sequence of the small-subunit (18S) rDNA was performed and the technique confirmed that the strain was unique. The extent of the divergence was large enough to describe the strain as a novel yeast species. Although from both the physiological and phylogenetic (26S and $18 \mathrm{~S}$ rDNA) point of view, the closest previously described species was Zygoascus hellenicus, the novel

The GenBank accession number for the $26 \mathrm{~S}$ rRNA sequence of strain CBS $8813^{\top}$ is AF294910. The GenBank accession numbers for the 18S rRNA sequences of strains CBS $8813^{\top}$ and CBS $6736^{\top}$ are AF294911 and AF294751, respectively. species was placed in the genus Candida. This was because ascospore formation was not observed and therefore it was not possible to place it in the teleomorphic genus Zygoascus. A complete description of the species is given and the name Candida bituminiphila is proposed.

\section{METHODS}

Organism studied. The strain was collected from tar in Canada. It was deposited at the Centraalbureau voor Schimmelcultures (CBS $8813^{\mathrm{T}}$ ) as a lyophilized and cryopreserved $\left(-130^{\circ} \mathrm{C}\right)$ culture. Duplicates of the strain have also been deposited at the Mycothèque de l'Université Catholique de Louvain (MUCL 41424 $)$. No additional information was available for the type strain (isolator, date and place of isolation, precise description of the substrate). No other isolate of the same species was available.

Physiology and morphology. Physiological and morphological characterization of the strain was performed as described by Robert et al. $(1994,1997)$ using the BioloMICS Automated Identification system (Robert \& Moenaert, 2000). This system employs conventional taxonomic criteria with 96 tests to assess growth, fermentative ability and morphology (Barnett et al., 2000; Yarrow, 1998) and 
Table 1. List of strains included in the physiological/morphological analysis and the $26 \mathrm{~S}$ rDNA data analysis

Culture collections are abbreviated as follows: CBS, Centraalbureau voor Schimmelcultures, Utrecht, The Netherlands; NRRL, ARS Culture Collection, National Center for Agricultural Utilization Research, Peoria, IL, USA. ${ }^{\mathrm{T}}$, Type strain; ${ }^{\mathrm{IT}}$, isotype strain.

\begin{tabular}{|c|c|c|}
\hline Species name & Strain designation & GenBank no. \\
\hline Arxula adeninivorans & CBS $8244^{\mathrm{T}}(=$ NRRL Y-17692 $)$ & U40094 \\
\hline Arxula terrestris & NRRL Y-17704 & U40103 \\
\hline Blastobotrys arbuscula & CBS $227.83^{\mathrm{T}}(=$ NRRL Y-17585 $)$ & U40108 \\
\hline Blastobotrys aristata & CBS 521.75 $(=$ NRRL Y-17579 $)$ & U40109 \\
\hline Blastobotrys capitulata & CBS $287.82^{\mathrm{T}}\left(=\right.$ NRRL Y $\left.-17573^{\mathrm{T}}\right)$ & U40104 \\
\hline Blastobotrys elegans & CBS $530.83^{\mathrm{T}}\left(=\right.$ NRRL Y-17572 ${ }^{\mathrm{T}}$ & U40095 \\
\hline Blastobotrys nivea & CBS $163.67^{\mathrm{T}}\left(=\right.$ NRRL Y-17581 $\left.{ }^{\mathrm{T}}\right)$ & U40110 \\
\hline Blastobotrys proliferans & CBS 522.75 $(=$ NRRL Y-17577 $)$ & U40098 \\
\hline Candida atlantica & CBS $5263^{\mathrm{T}}(=$ NRRL Y-17759 $)$ & U45799 \\
\hline Candida atmosphaerica & CBS $4547^{\mathrm{T}}(=$ NRRL Y-17642 $)$ & U45779 \\
\hline Candida bertae var. bertae & CBS $8169^{\mathrm{T}}\left(=\right.$ NRRL Y $\left.-17643^{\mathrm{T}}\right)$ & U70251 \\
\hline Candida bertae var. chiloensis & CBS $8168^{\mathrm{T}}(=$ NRRL Y-17646 $)$ & AF017236 \\
\hline Candida bituminiphila & CBS $8813^{\mathrm{T}}\left(=\right.$ MUCL $\left.41424^{\mathrm{T}}\right)$ & AF294910 \\
\hline Candida entomaea & CBS $6306 *(=$ NRRL Y-7785*) & U45790 \\
\hline Candida tammaniensis & CBS $8504^{\mathrm{T}}(=$ NRRL Y-8257 $)$ & AF017243 \\
\hline Cephaloascus albidus & CBS $389.77^{\mathrm{T}}\left(=\right.$ NRRL Y-7343 $\left.{ }^{\mathrm{T}}\right)$ & U39474 \\
\hline Stephanoascus ciferrii & CBS 5295' ${ }^{\text {IT }}\left(=\right.$ NRRL Y-10943 $\left.{ }^{\text {IT }}\right)$ & U40138 \\
\hline Stephanoascus farinosus & CBS $140.71^{\mathrm{T}}(=$ NRRL Y-17593' & $\mathrm{U} 40132$ \\
\hline Stephanoascus smithiae & NRRL Y-17849 & U76531 \\
\hline Sympodiomyces parvus & CBS $6147^{\mathrm{T}}(=$ NRRL Y-10004 $)$ & U40096 \\
\hline Zygoascus hellenicus & CBS 4099† (= NRRL Y-17319†) & U40125 \\
\hline
\end{tabular}

* Listed in GenBank as Candida entomaea van der Walt et al. Taxonomic synonym of Pichia mexicana Miranda et al. (Kurtzman, 1998).

$\dagger$ Type strain of Trichosporon hellenicum Verona \& Picci.

recognizes 719 described species of yeasts. Growth and fermentation tests were conducted in microplates. Assimilation test results were determined spectrophotometrically using an absorbance reader connected to a computer. Five replicates of the tests were performed on the same strain $\left(\right.$ CBS $\left.8813^{\mathrm{T}}\right)$ at different times. Fermentation tests were read manually. Identification of the strain was performed by computation of pairwise similarity coefficients using the BioloMICS software. A phenetic tree (UPGMA) was generated using a similarity matrix produced by the BioloMICS software. The closest species (see Table 1) were included in a phenetic analysis.

rDNA sequencing and sequence analysis. Cultures used for DNA isolations were grown in dextrose/yeast/peptone (DYP) broth for $24 \mathrm{~h}$ at $25^{\circ} \mathrm{C}$, harvested by centrifugation, resuspended in sterile water and transferred to $1.5 \mathrm{ml}$ microfuge tubes. Total nucleic acids were extracted following the protocol of Hoffman \& Winston (1987). Fragments that included approximately $600 \mathrm{bp}$ positions of the $5^{\prime}$ end of the 26S rRNA (D1/D2 region) gene were amplified by PCR using the external primers NL-1 and NL-4 (O'Donnell, 1993). Fragments that included approximately $1800 \mathrm{bp}$ positions of the $5^{\prime}$ end of the $18 \mathrm{~S}$ rRNA gene were amplified by PCR using the external primers NS1 and NS8 (White et al., 1990). Amplification reaction mixtures contained $5 \mu \mathrm{l}$ diluted DNA template ( $\sim 10 \mathrm{ng}), 5 \mu \mathrm{l}$ PCR buffer $(100 \mathrm{mM}$ Tris $/ \mathrm{HCl} \mathrm{pH} \mathrm{8.3,} 15 \mathrm{mM} \mathrm{MgCl}_{2}, 500 \mathrm{mM} \mathrm{KCl,} 1 \%$ Triton
$\mathrm{X}-100), 1 \mu \mathrm{l}$ dNTP $(10 \mathrm{mM}), 5 \mu \mathrm{l}$ each primer $(10 \mu \mathrm{M})$, $0.5 \mu \mathrm{l}(2.5 \mathrm{U}) \mathrm{Taq}$ DNA polymerase and $50 \mu \mathrm{l}$ sterile $\mathrm{H}_{2} \mathrm{O}$. Each sample was overlaid with $40 \mu \mathrm{l}$ mineral oil. Thermal cycling (DNA Thermo Cycler 480; Perkin-Elmer) parameters for amplification consisted of: an initial denaturation at $94{ }^{\circ} \mathrm{C}$ for $5 \mathrm{~min} ; 30$ cycles of denaturation at $94{ }^{\circ} \mathrm{C}$ for $5 \mathrm{~min}$, annealing at $52^{\circ} \mathrm{C}$ for $1 \mathrm{~min}$, extension at $72^{\circ} \mathrm{C}$ for $2 \mathrm{~min}$; and a final extension at $72^{\circ} \mathrm{C}$ for $10 \mathrm{~min}$. Amplified DNA was stored at $-18^{\circ} \mathrm{C}$ before purification using the QIAquick PCR purification kit (Qiagen). Sequencing reactions were performed using a Prism dye terminator cycle sequencing ready reaction kit (Applied Biosystems). Each reaction mixture included $4 \mu \mathrm{l}$ Half Term (Genpack). For the large subunit (strain CBS $8813^{\mathrm{T}}$ ), sequencing primers were NL-1 and NL-4 (same as for PCR); NL2A and NL3A were used as internal primers (Kurtzman \& Robnett, 1997). For the small subunit, strains CBS $8813^{\mathrm{T}}$ and CBS $6736^{\mathrm{T}}$ were sequenced using primers NS1-NS8 (White et al., 1990). Strain CBS $6736^{\mathrm{T}}$ is the type strain of Candida inositophila Nakase (anamorph of $Z$. hellenicus) complementary mating type of CBS 5839. The mated culture of these two strains is the type strain of $Z$. hellenicus (Smith, 1998). Excess dye terminators were removed by centrifugation using Centrisep columns (Princeton Separations) prior to analysis using an Applied Biosystems 373A DNA sequencer.

Sequences were edited and assembled using SEQUENCHER version 3.0 software (Gene Codes Corporation). Data were 
subjected to a basic GenBank BLASTN search (Altschul et al., 1990) to retrieve sequences of closely related taxa; these sequences, as well as those of physiologically and morphologically similar yeast species (see Table 1), were included in a multiple alignment generated using CLUSTAL W (gap creation penalty, 12; gap extension penalty, 2) for $26 \mathrm{~S}$ rDNA data. No manual adjustments were done except that the ends were trimmed. Phylogenetic relationships were inferred from this alignment using the general heuristic search option in PAUP version 3.1.1 (Swofford, 1993). Support for branches was evaluated by bootstrap analysis from 1000 heuristic searches. Distance matrices were produced using PAUP version 3.1.1 (Swofford, 1993). The pairwise alignment of $18 \mathrm{~S}$ rDNA sequences of $C$. bituminiphila and Z. hellenicus was done using the Smith-Waterman algorithm incorporated in the SSEARCH3 program from the FASTA package (gap creation penalty, 12; gap extension penalty, 2).

\section{RESULTS AND DISCUSSION}

\section{Latin diagnosis of Candida bituminiphila sp. nov.}

In extracto malti post 8 dies cultura cremea pallida, laevis, convexa, margine cellulosa. Cellulae $1 \cdot 2-2 \cdot 5 \times$ 2.5-8.0 $\mu \mathrm{m}$, ovoideae, ellipsoideae, citriformes, leviter allantoideae vel irregulares, singulae vel binae. Conidiophora brevia, sympodialiter proliferentia, numerosas gemmarum cicatrices ferentia, rhachidis similia, conidia singula vel plura ferentia. Pseudohyphae parcae, hyphae verae non observatae. Ascosporae, ballistosporae, arthroconidia et teliosporae absentes. In culturis Dalmau, pseudohyphae et hyphae verae praesentes. In DYP medium, post 2 hebdomades, sedimentum et annulus formantur. In 'corn meal', maltum, 'Gorodkowa', DYP et V8 agaro ascosporae absentes. D-Glucosum, Dgalactosum, trehalosum, cellobiosum fermentantur neque lactosum, maltosum, melezitosum, methyl $\alpha-\mathrm{D}-$ glucosidum, raffinosum, sucrosum, inulinum, amylum, melibiosum nec D-xylosum. D-Glucosum, D-galactosum,
L-sorbosum, D-glucosaminum, D-ribosum, D-xylosum, L-arabinosum, trehalosum, cellobiosum, salicinum, arbutinum, amylum solubile, glycerolum, D-glucitolum, D-mannitolum, D-glucuronatum, succinatum, mesoinositolum (exigue), DL-lactatum (exigue), ethanolum (lente), D-arabinosum (lente et variabiliter), sucrosum (lente et variabiliter), propanolum (variabiliter), maltosum (variabiliter), raffinosum (variabiliter), ribitolum (variabiliter), xylitolum (variabiliter), L-arabinitolum (variabiliter), D-glucono-1,5-lactonum (variabiliter), 5keto-D-gluconatum (variabiliter), D-gluconatum (variabile) assimilatur at non methyl $\alpha$-D-glucosidum, melibiosum, lactosum, melezitosum, inulinum, L-rhamnosum, erythritolum, galactitolum, 2-keto-D-gluconatum, D-galacturonatum, citratum, methanolum nec butanolum. Glucosaminum (variabiliter), L-lysinum (variabiliter), cadaverinum (variabiliter) assimilantur neque natrium nitricum, natrium nitrosum, creatinum, creatininum, ethylaminum et imidazolum. Ad crescentiam vitamina externa necessaria sunt: thiaminum, biotinum, thiaminum, pyridoxinum. Crescit sine meso-inositolo (variabiliter), pantothenato (lente), pyridoxino (variabiliter), niacino (lente), acido aminobenzoico (variabiliter). Maxima temperatura crescentiae: $30^{\circ} \mathrm{C}$. Crescit in medio $0.01 \%$ cycloheximidum continente, $0.1 \%$ cycloheximidum (lente) neque $50 \%$ D-glucosum. Urea non finditur, diazolium coeruleo $B$ probatio negativa. Amylum non formatur, arbutinum non finditur, acidum aceticum non formatur. Typus: stirps CBS $8813^{\mathrm{T}}(=$ MUCL 41424 $4^{\mathrm{T}}$ ), ex bitumine isolata. Holotypus lyophilus conservatur in collectione culturarum Centraalbureau voor Schimmelcultures, Trajectum ad Rhenum.

\section{Description of Candida bituminiphila sp. nov.}

Candida bituminiphila (bi.tu.mi.ni'phi.la. M.L. neut. n. bitumen, -inis asphalt, tar; Gr. adj. philos loving; N.L. fem. adj. bituminiphila tar-loving). (a)

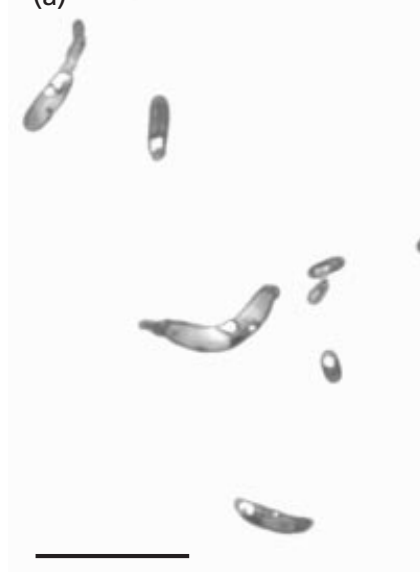

(b)

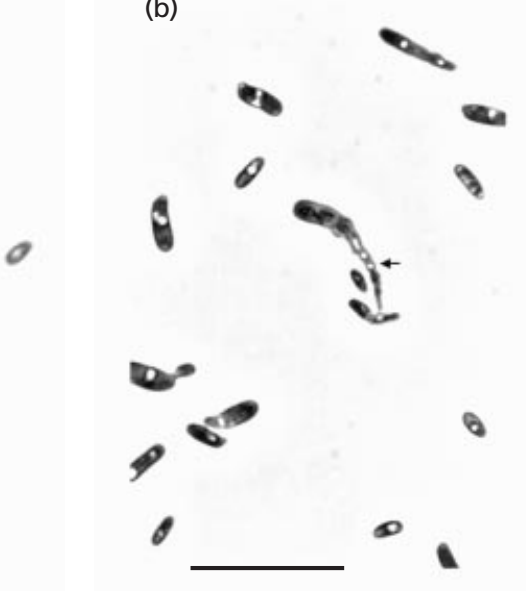

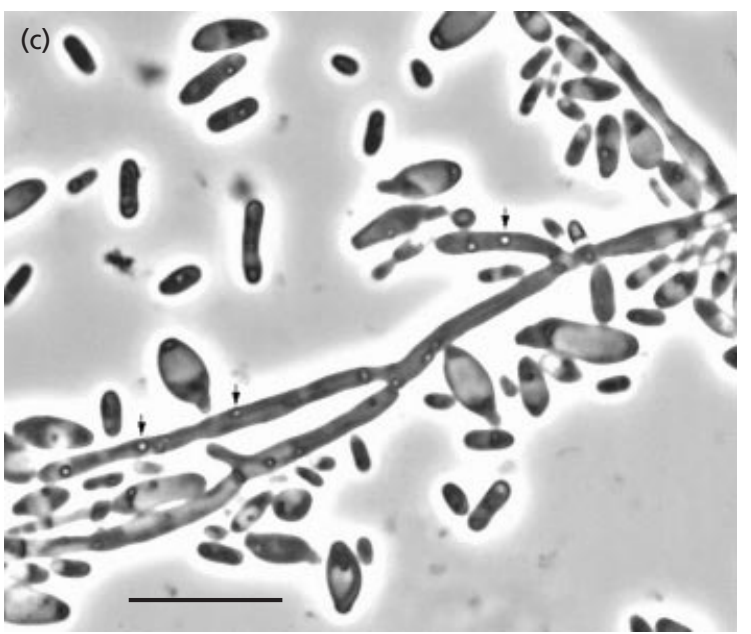

Fig. 1. Vegetative cells of C. bituminiphila CBS $8813^{\top}$ with some allantoid cells (a), with a rachis-like structure, see arrow (b). Extension of conidiophore with scars, see arrows (c). Grown on GPY agar for 1 week at $25^{\circ} \mathrm{C}$. Bars, $10 \mu \mathrm{m}$. 
Table 2. Physiological characteristics of the type strain (CBS $8813^{\top}$ ) of C. bituminiphila

-, Negative; +, positive; D, delayed positive (after $14 \mathrm{~d}$ or more); w, weak;,-+ , variable.

\begin{tabular}{|c|c|}
\hline Characteristic & Result \\
\hline \multicolumn{2}{|l|}{ Fermentation of: } \\
\hline D-Glucose & + \\
\hline D-Galactose & + \\
\hline Maltose & - \\
\hline Methyl $\alpha$-D-glucoside & - \\
\hline Sucrose & - \\
\hline$\alpha, \alpha$-Trehalose & + \\
\hline Lactose & - \\
\hline Cellobiose & + \\
\hline Melezitose & - \\
\hline Raffinose & - \\
\hline Inulin & - \\
\hline Starch & - \\
\hline \multicolumn{2}{|c|}{ Assimilation of (carbon compounds): } \\
\hline D-Glucose & + \\
\hline D-Galactose & + \\
\hline L-Sorbose & + \\
\hline D-Glucosamine & + \\
\hline D-Ribose & + \\
\hline D-Xylose & + \\
\hline L-Arabinose & + \\
\hline D-Arabinose & $\mathrm{D},-$ \\
\hline L-Rhamnose & - \\
\hline Sucrose & $\mathrm{D},-$ \\
\hline Maltose &,-+ \\
\hline$\alpha, \alpha$-Trehalose & + \\
\hline Methyl $\alpha$-D-glucoside & - \\
\hline Cellobiose & + \\
\hline Salicin & + \\
\hline Arbutin & + \\
\hline Melibiose & - \\
\hline Lactose & - \\
\hline Raffinose &,-+ \\
\hline Melezitose & - \\
\hline Inulin & - \\
\hline Soluble starch & + \\
\hline Glycerol & + \\
\hline Erythritol & - \\
\hline Ribitol &,-+ \\
\hline Xylitol &,-+ \\
\hline L-Arabinitol &,-+ \\
\hline D-Glucitol & + \\
\hline D-Mannitol & + \\
\hline Galactitol & - \\
\hline myo-Inositol & $\mathrm{w}$ \\
\hline D-Glucono-1,5-lactone &,-+ \\
\hline 2-Keto-D-gluconate & - \\
\hline 5-Keto-D-gluconate &,-+ \\
\hline D-Gluconate &,-+ \\
\hline D-Glucuronate & + \\
\hline D-Galacturonate & - \\
\hline DL-Lactate & $\mathrm{w}$ \\
\hline
\end{tabular}

Table 2 (cont.)

\begin{tabular}{|c|c|}
\hline Characteristic & Result \\
\hline Succinate & + \\
\hline Citrate & - \\
\hline Methanol & - \\
\hline Propane 1,2-diol &,-+ \\
\hline Butane 2,3-diol & - \\
\hline Ethanol & $\mathrm{D},+$ \\
\hline \multicolumn{2}{|c|}{ Assimilation of (nitrogen compounds): } \\
\hline Nitrate & - \\
\hline Nitrite & - \\
\hline Ethylamine & - \\
\hline L-Lysine &,-+ \\
\hline Cadaverine &,-+ \\
\hline Creatinine & - \\
\hline Glucosamine &,-+ \\
\hline Creatine & - \\
\hline Imidazole & - \\
\hline \multicolumn{2}{|c|}{ Growth in the absence of: } \\
\hline Vitamins & - \\
\hline myo-Inositol &,-+ \\
\hline Pantothenate & $\mathrm{D},+$ \\
\hline Biotin & - \\
\hline Thiamin & - \\
\hline Biotin + thiamin & - \\
\hline Pyridoxine &,-+ \\
\hline Pyridoxine + thiamin & - \\
\hline Niacin & $\mathrm{D},+$ \\
\hline PABA &,-+ \\
\hline
\end{tabular}

After $8 \mathrm{~d}$ on $5 \%$ malt extract agar at $20-22^{\circ} \mathrm{C}$, colonies are $3 \mathrm{~mm}$ in diameter, pale cream coloured, smooth, convex, with a glistening surface, a finely fimbriate margin and soft texture. Budding is unipolar or bipolar. Budding cells are $1 \cdot 2-2.5 \times 2 \cdot 5-8 \cdot 0 \mu \mathrm{m}$, ovoid, ellipsoid, citriform, allantoid or irregular (Fig. 1a). Conidiophores are usually short, producing blastoconidia on a sympodially proliferating apex that, at maturity, shows a rachis-like structure (Fig. 1b) with numerous slightly denticulate scars left after the dehiscence of conidia (Fig. 1c). Shapes and sizes of conidia are comparable with those of the budding cells. Pseudomycelium is rare and true mycelium is sparse. Ascospores and arthroconidia are absent. On Dalmau plate with potato dextrose agar after $8 \mathrm{~d}$ at $20-22{ }^{\circ} \mathrm{C}$, true mycelium is produced as well as pseudomycelium and a few budding cells. On DYP broth after 2 weeks, sedimentation and a ring pellicle are observed. No sexual reproduction has been observed on corn meal, malt, Gorodkowa, DYP or V8 agar. The fermentation of carbon compounds as well as the assimilation of carbon and nitrogen compounds, and the growth properties without some vitamin compounds are given in Table 2. Growth at 25 and $30{ }^{\circ} \mathrm{C}$ is positive. Growth at $35^{\circ} \mathrm{C}$ is negative. Growth on 


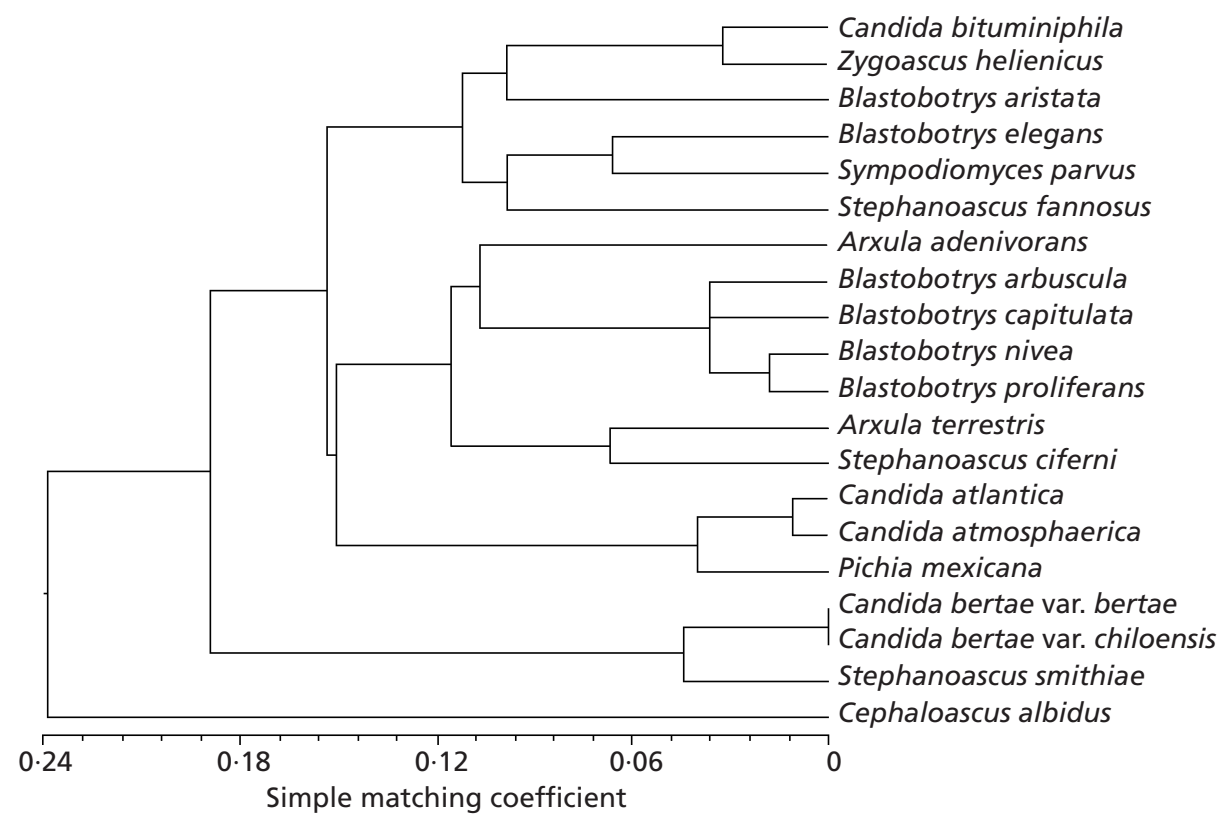

Fig. 2. UPGMA phenogram generated by the BioloMICS software based on pairwise similarity (simple matching coefficient) of physiological and morphological properties of the yeast species that are most similar to C. bituminiphila.

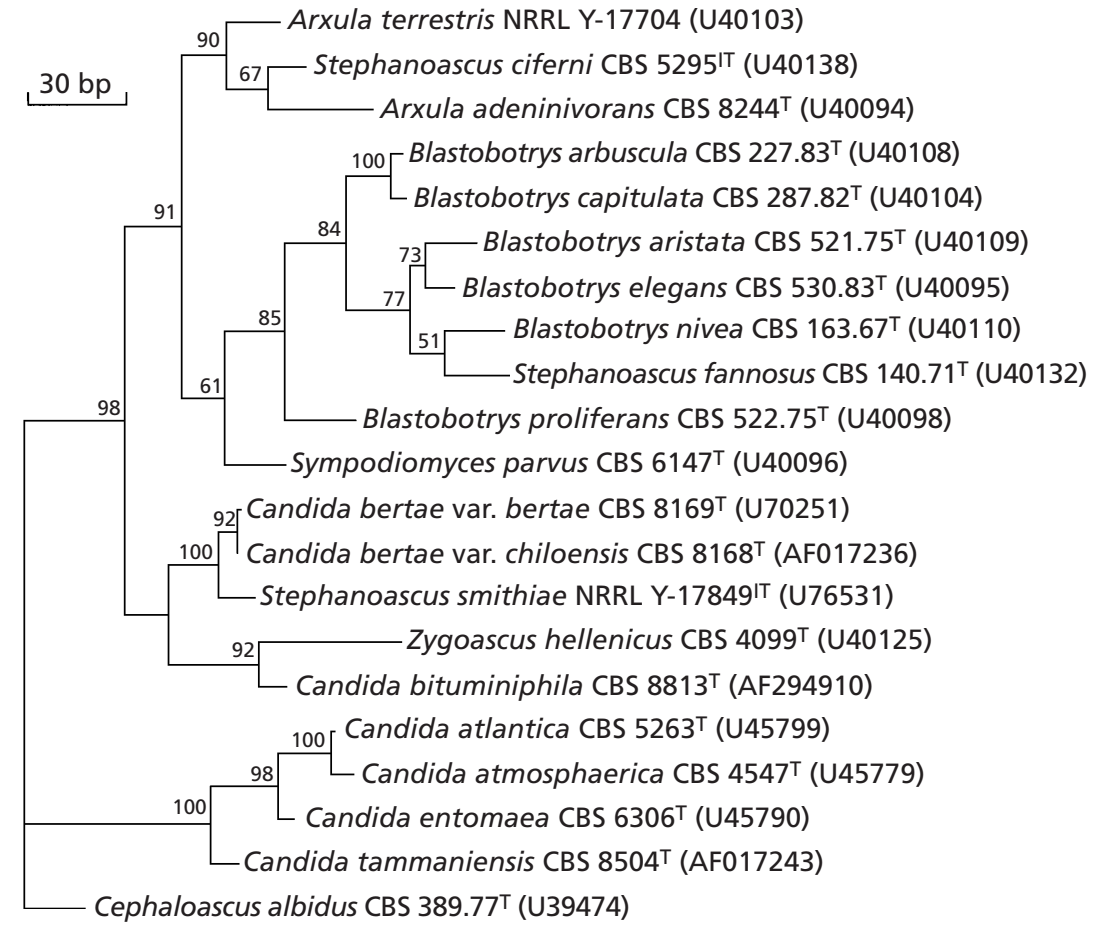

Fig. 3. Phylogenetic tree showing the placement of 21 species of yeasts most closely related to $C$. bituminiphila as inferred from 26S rDNA D1/D2 region sequence data. The tree is the most parsimonious tree of a bootstrap analysis with a heuristic search $(1000 ; 50 \%$ majorityrule consensus). Branch lengths are proportional to the number of nucleotide differences as indicated on the bar (30 bp substitutions). Bootstrap percentages (1000 replicates) above $50 \%$ are shown above branches.
$0.01 \%$ cycloheximide is positive, whereas growth on $0.1 \%$ cycloheximide is slow. No growth in presence of $50 \%$ D-glucose. No urea hydrolysis. Diazonium blue $\mathrm{B}$ reaction is negative. No starch formation. No acetic acid production. No arbutin hydrolysis. The type strain, CBS $8813^{\mathrm{T}}$ (= MUCL $\left.41424^{\mathrm{T}}\right)$, has been isolated from tar in Canada; no further information about strain origin was available.

\section{Phenotypic comparison with closely related species}

$Z$. hellenicus was physiologically the most similar species to C. bituminiphila (Fig. 2), but differs by its ability to grow on D-galacturonate and L-rhamnose and at $37^{\circ} \mathrm{C}$. The fermentation of sucrose was negative for $C$. bituminiphila but variable for $Z$. hellenicus. The two species also differed in the morphology of their 
vegetative cells (cells of $Z$. hellenicus are more regular in size and shape) and by the absence of ascospores in C. bituminiphila. Blastobotrys arbuscula, another physiologically similar species, differed by the fermentation of maltose and by the assimilation of erythritol, galactitol, salicin and arbutin. Blastobotrys aristata differed by the fermentation of maltose and by the assimilation of lactose, erythritol, galactitol and ethylamine. Although $C$. bituminiphila and Blastobotrys spp. shared several morphological characteristics, such as sympodial conidiophore proliferation and the ability to produce conidia on a rachis or laterally on hyphae, $C$. bituminiphila differed by failing to produce conidia in clusters. Sympodiomyces parvus was the most similar morphologically, but there were many physiological differences. $S$. parvus is nonfermentative and does not assimilate L-sorbose, salicin, soluble starch, DL-lactate or succinate. Also, C. bituminiphila can grow at $30^{\circ} \mathrm{C}$, unlike $S$. parvus.

\section{DNA relatedness studies}

A BLASTN search (26S rDNA) of GenBank and our own database allowed us to select the strains most closely related to $C$. bituminiphila. Z . hellenicus is the closest species to $C$. bituminiphila (54 bp substitutions in the large-subunit D1/D2 domains). Candida bertae var. bertae differed by $56 \mathrm{bp}$. The phylogenetic positioning of species compared to C. bituminiphila can be seen in Fig. 3. The high bootstrap value $(92 \%)$ supported the hypothesis that the novel species is phylogenetically related to $Z$. hellenicus. Pairwise alignment of the 18S rDNA region revealed $39 \mathrm{bp}$ substitutions in 1756 overlapping nucleotides, giving a $97 \cdot 8 \%$ identity between the two species. This evidence strongly supports the hypothesis that $C$. bituminiphila CBS $8813^{\mathrm{T}}$ is a novel species. Although strain CBS $8813^{\mathrm{T}}$ showed enough physiological and genetic (sequence) differences with the most similar existing genera to be placed into a novel genus, we believed that, since there was only one strain (with little data about its origin) the available information was not sufficient to allow this. It was therefore decided to place the species in the very broadly defined anamorphic genus Candida.

\section{ACKNOWLEDGEMENTS}

V.R. gratefully acknowledge the assistance of Pierre Evrard from the BCCM/MUCL for the physiological analyses, Walter Gams for the correction of the Latin description, and
David Yarrow and Richard Summerbell for critical reading of the manuscript. Financial support for part of this study was provided by the Belgian Federal Office for Scientific Technical and Cultural Affairs (OSTC), the Centraalbureau voor Schimmelcultures (CBS) and the Bundesministerium für Bildung und Forschung, Grant, Germany.

\section{REFERENCES}

Altschul, S. F., Gish, W., Miller, W., Myers, E. W. \& Lipman, D. J. (1990). A basic local alignment search tool. J Mol Biol 215, 403-410.

Barnett, J. A., Payne, R. W. \& Yarrow, D. (2000). Yeasts: Characteristics and Identification, 3rd edn. New York: Cambridge University Press.

Hoffman, C. S. \& Winston, F. (1987). A ten-minute DNA preparation from yeast efficiently releases autonomous plasmids for transformation of Escherichia coli. Gene 57, 267-272.

Kurtzman, C. P. (1998). Pichia E. C. Hansen emend. Kurtzman. In The Yeasts, a Taxonomic Study, 4th edn, pp. 77-100. Edited by C. P. Kurtzman \& J. W. Fell. Amsterdam: Elsevier.

Kurtzman, C. P. \& Robnett, C. J. (1997). Identification of clinically important ascomycetous yeasts based on nucleotide divergence in the $5^{\prime}$ end of the large-subunit (26S) ribosomal DNA gene. $J$ Clin Microbiol 35, 1216-1223.

O'Donnell, K. (1993). Fusarium and its near relatives. In The Fungal Holomorph: Mitotic, Meiotic and Pleomorphic Species in Fungal Systematics, pp. 225-233. Edited by D. R. Reynolds \& J. W. Taylor. Wallingford: CAB International.

Robert, V. \& Moenaert, B. (2000). BioloMICS a General Software for Biological Data Management Identification, Classification and Statistics. Brussels: BioAware.

Robert, V., de Bien, J.-E., Buyck, B. \& Hennebert, G. L. (1994). ALLEV, a new program for computer-assisted identification of yeasts. Taxon 43, 433-439.

Robert, V., Evrard, P. \& Hennebert, G. L. (1997). BCCM$\mathrm{TM} /$ Allev 2.00 an automated system for the identification of yeasts. Mycotaxon 64, 455-463.

Smith, M. T. (1998). The genus Zygoascus. In The Yeasts, a Taxonomic Study, 4th edn, pp. 422-423. Edited by C. P. Kurtzman \& J. W. Fell. Amsterdam: Elsevier.

Swofford, D. L. (1993). PAUP: phylogenetic analysis using parsimony, version 3.1.1. Illinois Natural History Survey, Champaign, IL, USA.

White, T. J., Bruns, T., Lee, S. \& Taylor, J. W. (1990). Amplification and direct sequencing of fungal ribosomal RNA genes for phylogenetics. In PCR Protocols: a Guide to Methods and Amplifications, pp. 315-322. Edited by M. A. Innis, D. H. Gelfand, J. J. Sninsky \& T. J. White. New York: Academic Press.

Yarrow, D. (1998). Methods for the isolation, maintenance and identification of yeasts. In The Yeasts, a Taxonomic Study, 4th edn, pp. 77-100. Edited by C. P. Kurtzman \& J. W. Fell. Amsterdam: Elsevier. 